\title{
On Unity and Disunity in the Sciences: Variations of Ancient Themata
}

\section{Citation}

Holton, Gerald. On Unity and Diversity in the Sciences: Variations of Ancient Themata. In On Unity and Diversity in the Sciences: Variations of Ancient Themata, eds. Manninen J., Stadler F, 245-262. Dordrecht: Springer Nature, 2010.

\section{Permanent link}

http://nrs.harvard.edu/urn-3:HUL.InstRepos:37856968

\section{Terms of Use}

This article was downloaded from Harvard University's DASH repository, and is made available under the terms and conditions applicable to Open Access Policy Articles, as set forth at http:// nrs.harvard.edu/urn-3:HUL.InstRepos:dash.current.terms-of-use\#OAP

\section{Share Your Story}

The Harvard community has made this article openly available.

Please share how this access benefits you. Submit a story.

Accessibility 
Published as „On Unity and Diversity in the Sciences: Variations of Ancient Themata“ 2010

May 13. 2008 ("Vienna III 08 long)

Draft for lecture, "Einheit und Vielheit der Wissenschaften-Variationen eines Dauerthemas,” for Vienna, June 2008

\section{by Gerald Holton}

I feel of course honored to be asked to speak at this university where so many ground-breaking scientists and philosophers were students or teaching, spreading their message world wide, despite resistance from within the dominant culture of the day. [There are of course Ernst Mach, Boltzmann, the extraordinary intellectuals around the circle of Moritz Schlick, but also such scientists as Schrödinger, Wolfgang Pauli, Victor Weisskopf, and world-renowned other scientists and scholars in those days and today also.] [Note: what is in [ ] is not to be translated.]

I am especially glad to have been asked to come by the Institut Wiener Kreis, of which I am proud to be a member, and whose splendid work for two decades and to this day is being carried out vigorously under Professor Stadler and his colleagues. Through that, a bright flame is being kept shining. That has its own salience. But I firmly believe, as you will hear later, that at just this time such studies can be an additional purpose, force and inspiration, in academe and society as well as in global policies that are now under our very eyes. All these contain an urge to bring about a new version of a unifying Weltauffassung. If that succeeds, historians of the future will perhaps say that there was a certain amount of pre-established harmony between the original Vienna Circle program, and what is now being done here, and a new, better world. 
Let me add two remarks about why being invited to speak here today is special for me. You have often seen the large, elegant building at the corner of Schottengasse and Schottenring. One of its high balconies were part of a Kanzlei of an attorney, specializing in international law, who had got his degree in jurisprudence right at this university, nearly a century ago. When his older boy visited him and looked out from that balcony, he could see the university where he hoped to study one day.

Secondly, I think I may be one of the last persons who had the privilege of being intellectually influenced to a large degree by the remnants of the Vienna Circle which came, as a result of the catastrophies of the 1930s, as refugees to the United States and started there a new branch, pursuing the old dream. On this aspect of the vertriebene Vernunft, much has been written. But let me single out one of these displaced intellectuals, Philipp Frank. He had previously studied and taught right here, then was for 26 years successor to the Mach-Einstein chair in Prague, coming to the meetings of the Wiener Kreis as often as he could. Of Philipp Frank, to whom I shall refer again, Herbert Feigl said that his work "combines informal logical analyses of the sciences with a vivid awareness of the psychological and social-cultural factors operating in the selection of problems and in the acceptance or rejection of hypotheses....In a sense, this is a genuine sequel to the work of Ernst Mach.” [p. 18 of Sci. \& AntiSci] . Professor Stadler has called Frank "one of the most important figures for the transfer, transformation and the further development of the Central European philosophy of science.” [p. 627, “History of the Philosophy of Science...”, 2002]. Frank, a student of Boltzmann, who also knew and consulted for Ernst Mach as a young Privatdozent in Vienna, at that time also participated, as you know well, in a series of generating events 
that eventually led to the formalization of the Vienna Circle, in which Frank became an active member.

In late 1938, Frank came to Harvard University at the invitation of its Physics Department, lead by P. W. Bridgman, who from 1945 on, supervised my doctoral thesis on experimental high-pressure physics. Bridgman, who was a crucial initiator of the Wiener Kreis re-established on the East Coast of America, may not by sufficiently known by some. I shall be glad to answer questions about him later. For about a dozen years, all three of us were in the same building. While still a graduate student, I was lucky to be asked by Frank to be his teaching assistant in his Physics and Philosophy courses, I shared his office, then became his colleague, and was asked by Frank to be the Secretary of his Inter-Scientific Discussion Group and of his Institute for the Unity of Science. Let me give you a smell of that heady atmosphere, those fourteen years, longer than the official years in Vienna. In the next building was Richard von Mieses, who never forgave me for turning down his request to translate his Positivism book manuscript into English. Also nearby were other sympathizers such as Van Quine, S. S. Stevens, E.G. Boring, Joseph Schumpeter, Gottfried Haberler, Harlow Shapley, Gyorgy Kepes, Wassily Leontief, Norbert Wiener, etc., later B. F. Skinner, visitors such as Ernest Nagel, Charles Morris, and many others. With all their differences, they agreed with one another, and even with Plato, that clear ideas drive out fantastical ones.

I was happy to get to know all of these scholars during our monthly meetings of the informal group, devoted to "fruitful mutual inspiration." As the saying goes, I imbibed some of the Vienna Circle ideas with my mother's milk. And I was especially attracted to their program, continued from the original Wiener Kreis, of trying to bring 
harmony between the philosophical, historical, and sociological contexts of science.

Indeed, their ambition was already to be found in Franz Sefarin Exner's famous Rectoral Rede of 1908-just 100 years ago. I mention this because that address was of great interest to Philipp Frank at that early phase. He referred to it not only in his Kausalgesetz book, twice, but again, in his late years in the unpublished Oral History interview, kept at the Center for History of Physics in America.

II

Now to the main body of my talk. But at this point you might expect me to clear up a seeming paradox. I have often written, in addition to the conventional parts of doing scientific research, also about the visual imagination in science, the metaphoric imagination, the aesthetic elements, and above all the thematic imagination, all of which are close to what Einstein once called his "irrational" parts in the pursuit of ideas, at least in the early stages of one's work. Put another way, at least the circle around Hans Reichenbach would not have approved of my interest in the context of discovery.

The seeming paradox I mentioned is that people in the transplanted Vienna Circle atmosphere on the East Coast of America did in fact not oppose my ideas, but rather supported them. Instead of looking for doctrinaire followers, they in fact, in their new environment, looked for extensions of ideas in new directions. They were generous and neugierig. And in any case, one had to accept the existence of, for example, the thematic analysis — which has some precursors such as Francis Bacon and passages in Karl Popper (Logic, 1959, 238)—since it springs out of the historical study of the documents and archives and publications of scientists in specific cases. The persistent hold of a thema or its antithemata, each with its saving flexibility, such as evolution or its opposites, 
devolution or steady state, or atomism and anti-atomism, discreteness or the continuum, and other such Dauer themata, can have an iron grip on the imagination of the scientist, often without proof or even despite contrary experimental disproof. But without some necessary presupposition, scientists could often not even know how to start. Einstein called his preoccupations and persistent presuppositions “categories in the non-Kantian sense,” since they are not a priori, but essentially subject to disproof or uselessness. In his Autobiographical Notes he celebrated the "constructive speculative character of...scientific thought,” but then became a prime example of the hold, to the bitter end, of the thematic concepts of the continuum (the field) and of causality in the strict sense. Similarly, one cannot imagine that a Parmenides could persuade a Heraclitus, or vice versa.

As Erwin Panofsky has pointed out, though Galileo of course knew of Kepler’s laws, he insisted on the more clumsy and less accurate circular motions as explanatory of planetary motions - a thematic presupposition aided by his aesthetic sense. Although originally little had been written or studied on thematic origins of scientific thought, we should not have been surprised by their pervasiveness. Our daily life and the decisions made are frequently on the basis of presuppositions that may turn out to be useful or not, wise or not.

Our very language is bifurcated, constructed to a large degree by synonyms and antonyms, as Peter Roget’s Thesaurus shows (analysis vs. synthesis, etc.), in historic studies (cyclicists such as Spengler vs. linearists), in politics (nationalists vs. cosmopolitans), in religion (fundamentalists vs. secularists), eros vs. thanátos, in music (classical vs. romantic; but in each of these cases, each portion is itself manifold—-think 
of the vast differences between Beethoven, Schubert, Brahms and Mahler, yet all with underlying romantic structure, as even sometimes Mozart, e.g., K516, $3^{\text {rd }}$ movement), in geography (even a Grossstadt vs. its greatly varying Bezirke), and of course in science (Copenhagen interpretation vs. Schrödinger; causality vs. probability and the whole Exerei, including Philipp Frank’s work on limits of causality; or Chicago-based Millikan’s allegiance to unitary electricity versus Vienna-based Felix Ehrenhaft's variety of subelectrons) - or even what is thought world is made of — particles and antiparticles (and eventually perhaps unparticles).

[Wars, too, are started on a firmly held presupposition, say, that the enemy has weapons of mass destruction, a position not revoked to this day.] Rarely do scientists switch from major preconceptions to the opposite. For example, Max Planck said in his 1910 Königsberg lecture, that to change from one working hypothesis to another, very different one, requires a change in one’s whole world view (Naturanschauung) or Weltbild, although he admitted in 1913 that this comment itself is only an unprovable hypothesis. (p. 14 DSB) No doubt Planck's opinion was colored by the fact that he himself famously switched around 1908 from Positivism to Metaphysics.

[Another very familiar case is that of Wilhelm Ostwald. As his biography stresses, he was not alone in being reluctant to accept Daltonian atomism until his conversion toward it. His anti-atomistic sentiments, as his biography puts it, "are closely connected with an aversion to mechanical doctrines and a strong belief in an energybased scientific program that he hoped eventually would encompass the natural and social sciences and the humanities in one vast monistic Weltanschauung.” It is therefore 
not surprising that Ostwald dedicated his Manifesto of 1902 on energetics to Ernst Mach, though Mach had little use for the energetics of Ostwald. (pp. 462-3, DSB, v. 15, supplement 1).]

And I cannot help but return to one of the most profound changes of a fundamental presupposition, the one by Johannes Kepler. We can pinpoint it to February 10, 1605, with immense consequences for the physical sciences. There he writes to his friend Herwart von Hohenburg, "I am much occupied with the investigation of the physical causes [of planetary motions]. My aim in this is to show that the celestial machine is to be likened not to a divine organism, but rather to a clockwork..., in so far as nearly all the manifold movements are carried out by means of a single, quite simple magnetic force, as in the case of a clockwork all motions (are caused) by a simple weight. Moreover, I show how this physical conception needs to be presented through calculation and geometry.” [p.56, TO, '88] With this change of mind and of soul, Kepler can be said really to have started the modern phase of physical science. We can forgive him that he thought gravity was caused by magnetism, a subject very fashionable at the time, and no great fault, the more so as we don’t really know yet what causes gravity.

Here one may well ask how the relatively few and rather stable themata have survived in science from antiquity to this day, and are still such strong guides and motivators. That is a large subject of its own, but here I can only point to possibilitythat the themata and antithemata need one another, that they are in symbiosis.

Something like it was already considered by the great Naturphilosoph Hans Christian Oersted, who wrote: 
"[We] have always a tendency to combine the phenomena and to discover their analogies; another class, on the contrary, employ all their efforts in showing the disparities of things. Both tendencies are necessary for the perfection of science, the one for its progress, the other for its correctness. The philosophers of the first of these classes are guided by the sense of unity throughout nature; the philosophers of the second have their minds more directed towards the certainty of our knowledge. This conflict of opinions keeps science alive, and promotes it by an oscillatory progress...” [Sci/Antici, 141]

A final theoretical, antifactual point about themata. Superficially they can change in time, but at base they do not. Change itself would serve as an example, as it is deallegorized and re-allegorized over centuries and decades. If I had time, I would sketch out the various stages from Aristotle, where change and motion are still entangled with each other, motion being one change, equally positioned with alteration in quantity or quality, generation or corruption. There followed at a distance the geometrization of motion at Merton College and by Nicole Oresme, the arithemetization of acceleration by Galileo, and on and one through Minkowski, Feynman's virtual particle exchange. But also Ernst Mach’s experiments on Bewegungsemfindungen (1875), which, to my surprise, has recently been translated into English in order to be part of the training of American Astronauts — taking Mach's ideas up into Heaven, and illustrating the manifold versions possible of an underlying ground motive. 
[From Science and the De-allegorization of Motion in Kepes' “The Nature and Art of Motion,” 1965] I now must draw your attention, for the sake of any important point to be made later, to a characteristic that thematic presuppositions often have, namely, that they can pass from an allegorical and even anthropomorphic form into a variety of de-allegorizations and re-allegorizations. As we shall hear, this is what happened to the old notions of unity and multiplicity, the thema and anti-thema. But let me give the example here of the case of change, specifically of motion.

Aristotle was not the first, but no doubt the most influential to propose that the notion of change and of motion are, as we would now say, entangled with each other, with local motion being just one example of change. In that rich context, alteration of the state of an object and its change of location are still combined. Whether it is a case of generation or corruption, an alteration in quality or in quantity, whether it is the occupation of different places--local motion in the narrow sense- - to Aristotle it is all under one roof. He wrote "motion is the actuality of that which is potentially viewed from the standpoint of potential being."

Without stopping at the intermediate stations, let me jump to the $14^{\text {th }}$ century, to the geometrization of motion at Merton College and by Nicole Oresme. Here I remind you of the mean speed rule, deduced on the basis of a geometric proof for an object where the question is What is the quantity of the quality of movement while it accelerates or decelerates. You remember the superposition of a large rectangular triangle and a rectangle of equal area. Here, motion as we understand it is important, but in the writings of these $14^{\text {th }}$-century philosophers that is merely one case where the quantity of a 
changing quality has to be expressed, whether it is an optical or dynamical problem or change of any kind. The mathematization of the allegory of motion has begun.

Three centuries later, Galileo uses the mean-speed rule, but adds to it. In the third day of the Discourse of 1638, the distance a body, starting from rest, covers in free fall, "during equal, intervals of time" is not as we teach it, given in terms of an equation. Instead, Galileo had his eye on numbers, 1, 3, 5, 7, or as he says, "the distances traversed...stand to one another in the same ration as the odd numbers beginning with unity.” As the science philosopher Alexandre Koyré put it, here was the true victory of the neo-Platonists—both geometry and whole numbers—-the language of nature. But it is victory at a sacrifice. Phenomena that can be handled in this way become considered to be primary quantities, and all that cannot, as in Galileo's day, taste, odors, colors, etc., become secondary qualities and are banished from scientific consideration for the time being. The rich prime concept or thema of change has been shorn of its difficulty but also of some of its humanity. Many have accused Galileo of starting the disenchantment of Nature. More and more, we see how the initially unitary concept of change, as of many themata, is subject to a su[perficial variety, to Vielheit.

Along the next stations is first Newton's first law of motion, conceived in an impossible Euclidean gravitation--free space. After that, motion is handled by differential equations and Fourier's harmonic analysis. Early in the twentieth century, after Boltzmann’s work on fluctuation phenomena, Einstein's Brownian Motion, opens up the chaotic motion in the sub-atomic world to vision, and again, Einstein in the first pages of his 1905 paper on relativity by introducing the concept of "event," and Minkowski's Parmedian crystal of world line. For presumed motions in the atom, Niels 
Bohr introduces the concept of allowed orbits whose radii are related to one another in the ratio of whole numbers. With quantum mechanics the motion is treated in terms of probabilities and Heisenberg's impotency principle that one cannot measure momentum at an atomic scale without changing it. Then in rapid sequence, the fall of parity, Feynman's virtual particle exchange, and on to today's grand proposals in greatly multiple-dimensional space.

With Ernst Mach’s portrait having greeted us again near the entrance to the university, and his work being so familiar to you, I speak about him only as often as absolutely necessary. But there is now one point in which Mach’s idea on motion may not be quite as familiar to you. A few years ago I was asked by Professor Laurence R. Young of the Massachusetts Institute of Technology to participate in the translation of Ernst Mach’s book of 1875, Grundlïnien der Lehre von den Bewegungsempfindungen. (Leipzig, 1875. 127 pp.) I was delighted to help because the book illuminates the kind of scientist-philosopher Mach was at the stage in 1875, and was to become in his later years. What that work may lack in the kind of sophisticated mathematical-theoretical prowess which we associate with many of late $19^{\text {th }}$-century physicists, it makes up by the careful accounts of the sophisticated and ingenious experimentation involving the sensation of the human body during motion.

There is also now a considerable scientific literature on movement perception, building on Mach’s findings of more than 130 years ago. [See CD-Rom at end of Young's book.] But I was eager to know why, after all these years, there would be a need for an English translation of that book. It turned out that ProfessorYoung, himself once having gone through training as a potential astronaut, found that the remarkable 
details Mach provided on the effects on human bodies of various rotations and the like are of great interest and value to those who are today training to be astronauts. So one can say that Mach’s ideas on notion have been taken to Heaven.

With this most recent version of the chosen thema change, we have come a long way from its beginnings, and witnessed its manifold versions of the underlying ground motive.]

\section{Start translation again here:}

$$
\text { IV }
$$

A similar fate befell the two of the most important thema-antithema couples I wish to present in this lecture. First the Absolutism and its main opposite, Relativism, each with its own Einheit und Vielheit, and finally the old dreams of Einheit und Vielheit themselves—all these of great antiquity as well as current excitements.

When we now mention the majestic concept of the Absolute, of course the figure of Newton arises, and also of Immanuel Kant, for whom it was the first of all categories. A nearly infinite amount has been written on this matter, but I want to draw attention in this setting only to Newton's choice of absolute space and time. For me, the briefest and truest observation on the subject was the observation of A. Rupert Hall and Marie Boas Hall [pp. 35-36, TO], namely that just as Newton knew well that the cause of gravity was God, “preferring God to Leibnitz.” Newton also knew that absolutes of space, time and of motion referred to the properties of events in God's "Sensorium" — the cut-off point beyond it was not possible to ask further questions. Here one can’t fail to recall Joseph Needham's opinion that the Scientific Revolution happened more easily in the Monotheistic West than in the East, to which Robert K. Merton’s work added the 
influence of the pious British Puritans on the rise of $17^{\text {th }}$-century sciences. Newton's private theologizing of physics reaches of course back to the position of scholars in medieval times and before. But while Newton's silence helped in the mechanization of the word picture Ernst Mach smelled out the metaphysics behind Newton’s mechanics, when Mach famously called absolutes of space and time “monstrous conceptions" $\left[7^{\text {th }}\right.$ edn. Paperback, p. 28 of Introduction and pp. 273 and 280]. Mach’s long attack on these conceptions brought his ideas into the cultural conversation of the time, and resonate to this day. In countering his opponents, he lauded what he called "relativists," from Stall0 to Petzoldt and Pearson [p.293]. As we know, we can include Einstein, who as late as August 1909, signed a letter to Mach with the words, “Ihr Sie Verehrende Schuler” [p.245, TO].

We may say that Mach’s influential relativism was to some degree a counterattack on one of the strands within early absolutism in physics, the theological and metaphysical aspects as well as ideological elements that underlay the mechanical-physical one. And this combination of force, on each side, can be discerned in the more recent debates on this dueling place, which, as you will see, extends even to the heights of positions both of church and of state.

I will skip the account of the attacks of Einstein Relativity Theory from 1920 on, as it is familiar to you.

\section{No translation here:}

[One such dueling place was Germany, from about 1920. For example, a socalled Working Party of German Scientists for the Preservation of a Pure Science, held a raucous meeting in the Great Hall of the Philharmonic Society in Berlin on 24 August 
1920, attacking Einstein and his theories. Einstein, calling it the "anti-relativistic association,” was so appalled that he toyed with the idea of leaving Germany right then and there, the more so as other such meetings soon followed. After 1933, this enmity to Einstein and his work became of course part of government policy. It was declared at the highest level that science must be understandable by the ordinary folk, because otherwise it “undermined people’s instinct of nature.” Most German scientists were of course appalled, but in teaching or in articles, whenever they had to refer to relativity theory, they had to deflect credit for it to ideologically more acceptable scientists such as $\mathrm{H}$. A. Lorentz, Henri Poincaré, and Friedrich Hasenoehrl. Even Werner Heisenberg, who continued to use relativity theory freely in his writings, was personally admonished by Heinrich Himmler.] (end of no translation)

To be sure, politically and ideologically based opposition to relativity theory and to Einstein was also present in the Soviet Union, and in China during Mao's regime. And evidence of rebellion against modern science flares up also in the USA. As one example among many, a widely read journalist, John Horgan, prophesized and urged "The End of Science” in his book with that title in 1996. And since then, in a long essay on this theme in the New York Times, John Horgan celebrated "commonsense" as a desirable alternative to much of modern science. The unforgivable sin of relativity theory, he said, was that it "shattered one's common-sense notions about how the world works."

Of course there are and have been more violent appearances against AntiAbsolutists in America. As the books by George Reisch and Deborah Coen document, ironically, Philipp Frank, refugee from fascist totalitarianism, in his late years in America became the victim of J. Edgar Hoover’s FBI, as did Rudolf Carnap, not least for their 
liberal use of such terms as "Unity" and "International," terms suspected of being keywords of left-wing totalitarians.

Among scientists, the antagonists against relativity theory have today shrunk to a mere handful. But there is now, and has been for a long time, a quite different set of disbelievers, not just in relativity but in the related notion of relativism. I now turn to them.

$\underline{\text { Some theological responses to relativity }}$

The complex responses of some theological authorities to new scientific thought is a well known story, starting long before the dispute between Galileo and the clergy.

But when Einstein's relativity theories eventually became widely admired, not just by most scientists, but—-to Einstein's ever-lasting puzzlement—also by the general public, various theologians became concerned to what extent that theory and its general point of view might infringe on the authority of the church. This came to Einstein's notice in an unexpected way in June 1921. When he was returning to Berlin from his first trip to America, he stopped in England. There, the Archbishop of Canterbury, the head of the Anglican Church, had been concerned about the possible consequences of relativity theory for religion. Dutifully, he had been trying to read several books on relativity. However, that conscientious task had, according to a friend of his, only driven him to "a state of intellectual desperation." So he asked to meet Einstein during his stay in London. A dinner was arranged. The Archbishop was placed to sit next to Einstein, and asked him quite bluntly what effect relativity would have on religion. Einstein answered simply, "None. Relativity is a purely scientific matter and has nothing to do with religion.” 
This response reassured that theologian. But others were not so easily satisfied. Among them was the prominent Cardinal O’Connell, Archbishop of Boston. In one of his speeches, he put his finger on an old and powerful accusation by some clergy that relativity, like evolution before it, was to be rejected because, as he put it, "they were mainly materialistic and therefore unable to stand the test of time.” And he added that Einstein’s theory was a “befogged speculation producing universal doubt about God and His creation,” implying “the ghastly apparition of atheism.”

While Cardinal O’Connell's judgment was typical only of a small segment of the clergy, I want to look briefly at the severe unease felt by two other theologians, who responded to relativity and its implications from a more sophisticated base.

The first of these is Paul Tillich, one of the most intellectually engaged and widely admired persons in his field in the twentieth century. In 1933, after having been dismissed from his position at the University of Frankfurt, he came as an exile to the United States, and for many years was a colleague of mine at Harvard University. He was a spellbinding teacher and extraordinarily productive writer. In 1928, he had met Einstein and heard him lecture, and became interested in the very question that had puzzled the Archbishop of Canterbury, namely, what consequences Einstein's ideas and point of view might have for religious thought.

Tillich’s early position was in fact along the lines of Einstein's reply to the Archbishop. Writing in his book Dynamics of Faith, Tillich stated "Scientific truth and the truth of faith do not belong in the same dimension of meaning. Science has no right and no power to interfere with faith, and faith has no power to interfere with science. One dimension of meaning is not able to interfere with another dimension.” 
But as time went on, Tillich became more and more alarmed by what he thought Einstein was saying and writing. Between 1930 and 1948 Einstein had published several widely discussed articles on religion and science, a project by which Einstein was inventing his own religion, namely “cosmic religion,” just as he had invented his science. In one of these essays, Einstein explained that the concept of a personal God was an anthropomorphic remnant of primitive times, of a "religion of fear." This primal urge, he advised, had to be abandoned in favor of a Spinozistic feeling of awe and sense of wonder at the rationality and beauty of the universe. Moreover, as a believer in strict causality throughout the universe, very much in the sense of Newton's physics, Einstein said he could not "entertain for a moment...the idea of a Being who interferes in the course of events,” such as causing prayers to be answered and miracles to occur. Einstein concluded that "serious scientific workers are the only profoundly religious people.”

By 1940, Paul Tillich had enough of that. While he did not mention relativity theory explicitly, Tillich thought, like the two Cardinals I mentioned before, that Einstein's ideas, especially because of his world-wide fame, might constitute a challenge to a key doctrine at the base of the authority of religion. Thus Tillich issued a manifesto in 1940 entitled "Science and Theology: A Discussion with Einstein.” His sharp attack ended with the statement "As the philosopher Schelling said: 'Only a person can heal a person.' This is the reason that the symbol of the Personal God is indispensable for a living religion.”

So much for Einstein's cosmic religion. But Tillich sensed that behind it there loomed a powerful viewpoint embodied in Einstein's relativity theory, and that had to be dealt with also. So toward the end of his life Tillich wrote a book with the 
straightforward title My Search for Absolutes (published in 1967). There he closed in on what was to him the most dangerous enemy. Tillich was writing, as he put it, "out of a feeling of uneasiness-uneasiness about the victory of relativism in all realms of thought and life today... a total victory....The sea of relativities...threatens to overwhelm us.” What Tillich called "the great spectacle of scientific relativism” was now, in his view, invading contemporary philosophy, ethics and most vexing of all, religion itself through the "secularist criticism of religion.”

Against all of this, Tillich said that he stood for “Absolutes.” Absolutes make language possible, understanding possible, truth possible. They are at the bottom of the “moral imperative." Indeed, "The experience of the Absolute-itself is the experience of the holy, the sacred.” I regard these declarations of Paul Tillich, with whwich Newton would have agreed in his heart of hearts, as the best succinct confrontation of Absolutism against Relativism.

Frank and Einstein on relativism

In 1950, there appeared a book important for our story (a German edition appeared in 1952). The author was Philipp Frank. Frank’s book of 1950 has the challenging title Relativity: A Richer Truth. Frank certainly knew about relativity. When still in Vienna after getting his doctorate in 1907, Frank wrote many of the earliest technical publications explaining the special theory of relativity to physicists. I need not here refer to the relativism and pluralism of the other members of the early and later Vienna Circle, only to remind you of Professor Stadler's work on this, for example his remark (in his article, "History of the Philosophy of Science....” 2007) that "Neurath remained very skeptical of explanations on the basis of one method and one image of 
science without pragmatically relativizing the field of 'Prediction and Induction' (1946). And again: Neurath “defended Logical Empiricism as “Through and through 'Pluralist.'” [pp.606-7 in F.S. article]

As to Frank's book of 1950, he distinguished in it between two opposites: on the one hand, “relativism,” which he defined as a "common form of thought...frequently regarded as an effect of the allegedly exaggerated role science has played in modern thinking," and on the other hand, fundamentalism, or the belief in absolute values. He then made the important distinction between relativism within science, which he celebrated, and which after all gave us relativity theory, and, on the other side, relativism outside science, which Frank called a largely illegitimate translation of the concept from science to ethical or social beliefs_-with one exception.

Indeed, the whole short but fervently written book by Frank is about that one exception, the one legitimate transfer from relativistic science to the other parts of culture and life. Thus, Frank argues, in science one learns that "a statement of the type 'this table is three feet long,' without also mentioning a system of reference, is a statement too poor to describe adequately our experience about length. We need to use a richer language, one that contains statements of the type 'this table is three feet long relative to the coordinate system of this room,"” and not with respect to some other, relatively moving coordinate system, because there the length measurement of the table would be different, perhaps only $2 \frac{1}{2}$ feet.

In the same way, Frank continues, but somehow again hints at a theological subtext. He writes: “A man who declines to answer by a flat Yes or No the question: “Do you believe in God?"” should not be called a skeptic or relativist or agnostic, because 
the question, Does a person believe in God, depends on what kind of life this person leads, so as to distinguish between the effective parts of his religion from the merely verbal ones. Similarly, terms such as freedom, democracy and the like make sense only in terms of their operational meaning, just as the length of a table depends on the specification of the reference system within which the length is measured. In short, Frank's book was yet another attempt to persuade, by skeptical rationalism and empiricism, those who preferred absolutism and relying on revelation.

Frank's book is also unusual in that it has a remarkable Foreword, an essay by Albert Einstein. Einstein's title is nothing less than "The laws of science and the laws of ethics.” Science itself, Einstein reports, has properly nothing to say about values, purpose, emotions and the like. "It cannot produce ethical directives." However, he continues, there are two ways in which science is related to ethics. One is that the habit of logical thinking and the search for empirical facts are important and useful, both in science and in other fields. Frank's book was of course largely devoted to urging that point. But the second relationship, Einstein continues, is that the mechanism by which true and useful results may be obtained is the same, both in science and in ethics. That is, in both fields one should start with fundamental premises or propositions, and from these, other propositions can be derived by logic, both in physics and in ethics.

In fact, in this Foreword, Einstein was transferring to ethics his own favorite method of theory construction in science. For example, Einstein had jumped at the very start of his relativity theory paper to the two principles or axioms of relativity-generalizing Galilean relativity to all of physics, and the constancy of light postulateand then deriving almost everything else from them. 
Now, in his Foreword to Frank’s book, Einstein advised the same method for finding answers to ethical problems, by setting up first a set of ethical axioms and deducing their consequences. But of course there is a difficulty, so Einstein asks, "what is the origin of such ethical axioms?” From the logical point of view, all axioms are arbitrary, and there are infinitely many of them. How to chose the right ones? Here, Einstein continues happily, there do exist "inspired individuals," who can be the source of “comprehensive” and "well founded” ethical axioms. Elsewhere Einstein named three such inspired individuals: Moses, Jesus and Buddha—all together.

So far so good. But at this point Einstein turns around 180 degrees. Far from granting anyone an unquestionable inspiration by divine revelation, as religious fundamentalists would desire, Einstein, in the last two sentences of his Foreword, subjects the supposedly inspired ethical axioms to tests for their actual effectiveness in practice. He writes: “Ethical axioms are...tested not very differently from the axioms of science....Truth is what stands the test of experience." With this science, Einstein essentially repeated Carnap’s 1928 test of Prüfbarkeit of ethics, and also anticipated the chapter on ethics in the book by von Mises. So in Einstein's opinion, ethical axioms, far from being true and infallible just by announcement, can change or even be cast aside when skeptical investigation so requires, just as in the case for the axioms in science. It is a key point for Einstein. All the conciliatory skill Philipp Frank shows in the body of his book can’t undo Einstein's operationalist tests of ethics. One may say that these declarations of Einstein are the best succinct confrontation of a form of Relativism against a form of Absolutism. 
Let us take a moment to look at the definition of relativism. Since the early $20^{\text {th }}$ century, relativism more often than not was held to be a point of view, both in science and outside, fostered by Relativity theory. But the word relativity, which came into the English language in mid- $19^{\text {th }}$-century, connotes a much older point of view. As the Oxford English Dictionary puts it, in relativism knowledge is only of relations; therefore “truth, morality, etc., are relative to situation and are not absolute.” Thus, meanings can fluctuate from place to place and time to time. The allegory can be reallergorized .

At the extreme, some non-scientific postmodernists hold that all beliefs are equally valid, since they are all "socially constructed.” For example, the widely read Professor Stanley Fish, then at Duke University, famously wrote that the laws of nature which scientists deal with are just as arbitrary as the rules of a sport of baseball. One might well say that this is one version of relativism run amok. Even Bruno Latour, once one of the icons of postmodernism, quoted this example in his famous mea culpa article (Critical Inquiry, 30, Winter 2004), in which he accused himself of having for a long time undermined the scientific Weltauffassung.

A far more profound and important indication of the differing claims of authority came to a head three years ago in Rome. According to the official Vatican transcript, on Monday, 18 April 2005, while delivering a Homily in the Vatican Basilica in St. Peter’s cathedral, His Eminence Cardinal Joseph Ratzinger, the Dean of the College of Cardinals and for twenty-three years Prefect of the Congregation of the Doctrine of Faith, quoted St. Paul's warning not to allow oneself to be “tossed here and there, carried about by every wind....” The Cardinal gave examples of such tossings, but concluded the list with the one example that he evidently held to be the most dangerous one today: It is, in his 
words, "Relativism...the only attitude that [it is believed] can cope with modern times." He continued, “There has been building up [Es ensteht] a dictatorship of relativism that does not recognize anything as definite....”

These words were widely noted when the following day the College of Cardinals elected Cardinal Ratzinger to be the new Pope. Those who had studied his writings and speeches were already familiar with his point of view.

And as the U.S. weekly journal The National Catholic Reporter put it (22 April 2005), the new Pontiff saw the "flaw in theologies of pluralism" to be "the dogmatic relativism that follows Immanuel Kant and the Enlightenment in pushing the question of truth toward science and away from questions of human meaning and value.” As a consequence, "tolerance and appreciation of cultural diversity emerge as inviolable principles.” It will obviously be fascinating to watch the consequences of these challenging views, the more so as just this April 15, 2008, almost precisely three years after becoming Pope, Benedict XVI was greeted by President George W. Bush on arriving in the USA for his visit, with the President's speech warmly endorsing and repeating the phrase, "the dictatorship of relativism.”

$\mathrm{V}$

\section{$\underline{\text { Philosophers }}$}

I turn now to typical reactions among recent and current philosophers who also participated in debates about relativism. I leave aside non-philosophers such as Lenin, who launched in 1908, in Materialism and Emperio-criticism, his attack on relativity 
theory as Kantian idealism, and also Oswald Spengler who publilshed in 1918 that the rise of relativity theory is part of the death of Western culture. I turn very briefly to a few recent and contemporary philosophers. Thus, Hilary Putnam, in his book Reason, Truth and History, attacked a number of his fellow scholars to be relativists, including Richard Rorty and Paul Feyerabend. Rorty responded in his book Objectivity, Relativism, and Truth, by dismissing the unacceptability of relativism in the following, somewhat contorted passage. “'Evidence' is not a very useful notion when trying to decide what one thinks of the world as a whole. Such an admission only looks relativistic if one thinks that owing to the lack of general neutral antecedently formulable criteria for choosing between alternative, among equally coherent webs of belief there can be no 'rational' decision. Relativism seems a threat only to those who insist on quick fixes and knockdown arguments.”

On the other hand, Paul Feyerabend openly flaunted his relativism, famously in his book Against Method, where he applied it to science itself. There he wrote that there is no such thing as scientific method, a conclusion that has political implications. One of them is that in Feyerabend's opinion the activities of scientists should be subjected to what he called “democratic relativism,” which means, for example, that lay people and “democratic councils" should be evaluating the work of the scientists. This is of course close to what is now happening in the United States, where Congress and the Administration are trying either to censure or dismiss findings of scientists on such matters as climate change. Feyerabend wrote in the same vein that the belief in rationality "may...be nothing but a pious wish....There is not one rationality, there are many, and it is up to us to choose the one we like the best.” 
One could spend many weeks among the numerous books that deal, positively or negatively, with relativism. I shall just mention two serious ones. One is by Joseph Runzo, titled Reason, Relativism and God (1986). It systematically exposes scholars whom he regards to be relativists in various professions, such as the anthropologist Ruth Benedict, the sociologist Peter Berger, the psychologist Jean Piaget, even the novelist William Faulkner, and of course Thomas Kuhn, the inventor of the succession of revolutions in science, each revolution appearing equally plausible, and separated from the previous as well as the next ones by a barrier of incommensurability.

Perhaps a favorite among all these books is that of the venerable art historian Ernst Gombrich, titled Topics of our Time: Twentieth-Century Issues in Learning and Art (1991). Gombrich begins by reminding his readers of Goethe's belief in the universality of human nature and contrasts it with Hegel's philosophy of history. On the latter, Gombrich says, "Right at the beginning Hegel formulates the opposite view, which I should like briefly to characterize as 'cultural relativism.’” And Gombrich quotes Hegel as follows: "Every age has such peculiar circumstances, such individual conditions, that it must be interpreted...by reference to itself."

Of course, Gombrich does not deny that, as he put it, "ages and people differ from each other. We all know that.” But "what makes the cultural historian into a cultural relativist is the conclusion which we saw Hegel draw, that cultures and styles of life are not only different but wholly incommensurable. In other words, that it is absurd to compare the peoples of a region or an age with human being of other zones or periods because there is no common denominator that would offer us a yardstick....[Cultural 
relativists] refuse to acknowledge any constancy that would enable us to recognize a permanent human nature behind all changing appearances.”

\section{The earliest roots}

Gombrich could have gone further back than Hegel to discover the ancient roots of relativism. Many scholars point to the implicit debate between the SophistPhilosopher Protagoras (490-420 BC) and Plato (427-347 BC). Robert W. Jordan put it in his book, Plato’s Revolt Against Relativism, that Plato, especially in his Dialogue Phaedo, tried to identify what remains unchanged, universal, absolute, and constant despite all appearance of diversity, "all Becoming and Change, all birth and decay." That universal absolute was for Plato "the immortality of the reincarnated soul." By contrast, perhaps the earliest expression of relativism in philosophy is the famous dictum of Protagoras that "Man is the measure of all things."

Unlike philosophers, historians tend to put the beginning of relativism in history on the shoulders of Herodotus (484-425 BC). While Herodotus still reports myth and religious beliefs with relish, he gives, perhaps for the first time, a desacralized sort of history. The gods of Olympus may still be meddling with mankind, but that is something Herodotus avoids, preferring not to "fall into the traps of the supernatural."1 Herodotus rather chronicles the "great men, great cities, and great deeds," and is intensely interested in the variety of human behavior. He delights in information such as this: "To some of the Egyptians, the crocodile is sacred, but for some it is not—in fact, they regard it as an enemy.” Elsewhere: Among the Lydians, for a person "to be seen naked is an occasion

\footnotetext{
${ }^{1}$ Quotations are from History by Herodotus. Translation by David Grene, University of California Press, 1987.
} 
of great shame;” but not so in Greece. In short, as his commentator David Grene puts it, Herodotus wrote, “a kind of universal history; it is the record of all the logical possibilities, political and human, that coexist in the human world.” Nothing absolute there.

The important fight in our culture between the claims of relativism and absolutism has gone on for some 2500 years, since Protagoras versus Plato. It is very alive today, and it may never end. Einstein and the Vienna Circle found themselves entangled in this fight, and the uses and abuses made of their ideas have become part of our intellectual history

\section{Part VI}

When we finally come to speak of the antonyms of Unity versus Disunity, each shows again the inherent multi-allegorical substructure. The thema of Unity is perhaps historically the most ancient dream of nature philosophy, but also is said, by some psychologists, to be one of the earliest experiences of the child with respect to the mother. It would be presumptuous to lecture to a learned audience of the Institut Wiener Kreis about all the vagaries of the notion of Einheit vs. Vielheit in science and philosophy. But it is worthwhile to recall that the early decade or so of the $20^{\text {th }}$ century was a great period of experimentation in this debate. Neurath, Hahn, Frank, von Mieses, and students at the Vienna University were famously meeting in one of the old coffee houses - the embryonic or first form of the unity-seeking Vienna circle, at just that time when the American historian Henry Adams was writing his autobiography (The Education of Henry Adams). There he was fascinated by the recent discovery of 
radioactivity, and to him the probabilistic, apparently a-causal radiations coming with violent force from those atoms indicated to him the coming of a vast change in world conception: away from the vestiges of cultural unity and continuity, represented by the grand cathedral of Chartres for previous centuries, and onward toward disunities, discontinuities, and fragmentations that would characterize a chaotic new $20^{\text {th }}$ century. In the same spirit, the 1911 Solvay Conference on the new quantum physics signaled the ending of the Newtonian classical coherence and continuity, leading Henri Poincaré to exclaim in anguish: "Is discontinuity destined to rein over the physical universe, and will its triumph be final?” \{p. 159 TO]

It is not unconnected that elsewhere in European culture, during those volcanic years at the beginning of the new century, there were also extreme challenges to the reigning worldview. One need only mention Dada in the arts, Kokoschka and the Expressionists, Stravinsky’s “Rite of Spring,” the Viennese Schönberg, Webern, and Berg in atonal music, and the transforming new technologies.

One may perhaps say that those brave academics, who found refuge in those coffeehouses, were re-asserting the capability of the clear mind to reach to basic unities. They had many enemies, but also some allies.

\section{VII}

One ally, of whom the Viennese may not have known then, was the Belgian mathematician George Sarton, who later became known as the father of modern history of science. He founded the journal Isis, and launched it in 1912 with a 39page manifesto. There he laid out a visionary program for the new profession. It has 
four components: to produce a complete and synthesizing manual of the history of science; to assure that the pedagogic presentations of science should be in historical sequence; to contribute to a synthèse of the study of mankind; and to rebuild, on solid scientific and historic knowledge, the philosophical work begun by Auguste Comte.

Sarton's project is dazzling in its missionary aim and far-reaching extent. A close reading of his essay adds even more tasks to be met. Thus Sarton deplores the danger of "disaggregation" and ever more limited subdivision of the work of scientists, which he says not only threatens any common understanding among scientists themselves, but endangers the sharing of a common viewpoint of mankind itself. The healing power here, too, Sarton hints repeatedly, will come from recognizing the need for synthesis. In the conclusion, Sarton summarizes that Isis will be "a critical review, an international one, in a certain manner a dogmatic one," but first of all it will be "une revue de synthése."

That aim fitted well with one component of the beleaguered Zeitgeist of the time. Thus, one development Sarton reported on in his first issue was on the formation of a new international positivistic society. He was referring to the ambitious if short-lived Gesellschaft für positivistische Philosophie, which came into being through a manifesto (“Aufruf'), published and circulated widely about a year before Number 1 of Isis. The Aufruf overlapped significantly with Sarton's own program, as indicated by the names of its thirty-three signers from a great variety of fields, such as Hilbert, Mach, Einstein, Freud, Helm, F. Klein, J. C. S. Schiller, Tönnies, and Jacques Loeb, a positivist of Mach's variety. And the audacious program of that new society, quite parallel to that of the first Wiener Kreis, was nothing less than this: [The Gesellschaft[ Zweck haben, alle Wissenschaften untereinander in lebendige Verbindung zu setzen, überall die vereinheitlichenden 
Begriffe zu entwickeln und so zu einer widerspruchsirzien Gesamtauffassung vorzudringen.

One can see the work being done in the same decade or two by physicists such as Boltzmann, Planck and Einstein, as crashing through current doctrines. Their thematic antithesis against the old order is part of the many colored allegories, each with its long history, and is very much alive today. But those physicists and other scientists (not excluding Freud) as well as philosophers sympathetic to them in those early decades, were breaking away from the old unities—not to join the disunifiers, but in their different ways to forge new unities, often again severe internal and external obstacles. (The word "despair" occurs in the writings of many of these scientists.)

The variously admired forebears of many in this Gesellschaft were the philosophers of the Enlightenment, Auguste Comte, Maxwell, Helmholtz, Mach, Pearson. However, the Canadian philosopher Ian Hacking thinks he can discern Vielheiten in the Einheit they and their predecessors clung to. He cites three main family varieties of unity in science. [In Peter Galison and David J. Stump, editors, The Disunity of Science, 1996.] He cites as the first family the metaphysical one, "a collection of ideas about what there is.” (p.43) There he focuses on Salam, Weinberg, and Glashow's successful reunification of the three main forces in physics, praising their “interconnectedness.”

His second family "is a collection of practical precepts about the sciences-the [method and the aims of the sciences]. Here, he focuses on finding "connections between important phenomena” (all p. 43) and praises Dirac for having united theories that were previously disjointed. (p. 51) He also singles out Adorno and Popper as representative 
of the trend to use "the same method (whatever it is)...to be used in all the sciences, natural, social and human.” (p.52)

His “third family forms a set of theses about scientific reasoning, and includes both logic and methodology.” (p.43) And under this heading he singles out the "unity of science manifesto issued by Helmholtz and others in 1847” (p. 53) as well as Darwin, Crick, and at last Ernst Mach.

I don’t wish to imply that I accept all these divisions as my own, but they are characteristic of contemporary philosophers of science. But I do find myself in full sympathy with Professor Hacking’s remark (p. 67) that "many of the present youngest generation of disunifiers are quite cynical not only about established images of science but about the sciences themselves.”

But at this point, I should draw attention to one other, little acknowledged set of allies of the first Vienna Circle, one that happened also a century ago, also in Vienna, and which Eric Kandel has been studying in hi s remarkable way. I refer to a variant of Einheit, to the extraordinary subterranean integrations in the unique cultural life of Vienna in the two decades on either side of fin-de-siecle. Members of the artistic and intellectual elites not only met and learned from one another in the salons and coffee houses, but brought into them results of their own respective studies and labors what they had learned from one another. One example among many was the influences of Freud and the inheritors of the school of Rikotansky on Austrian Expressionist artists such as Klimt, Kokoschka and Schiele.

For me the most striking fact about those unifiers is their sharing in the ancient dream, their high and serious ambitions, especially when measured against the scientific, 
philosophical and political forces in charge in those days. Against those forces, and especially in the days of the Vienna Circle, its activities were quite breathtaking courageous engagements. The historian of ideas, Isaiah Berlin, cautioned not to use the word "great" or "greatness" too easily. But surely we can apply it to the Vienna Circle then and to those who study it now. By Isaiah Berlin's own definition, that greatness implies taking "a large step, one far beyond the normal capacities of normal persons...to permanently and radically alter the outlook and values of a significant body of human beings.” (Berlin, Personal Impressions, NY: Viking Press, 1981, pp. 32-33)

In concluding, I remember that on must, even in theoretical discussion, return, as the 1929 Manifesto put it, to the questions of life and Otto Neurath's warning to attend, in his words, to "the great historic process going on in the world." That process is today still as it was then, in Sigmund Freud's characterization, the combat between the antithetical themata, eros and thanátos.

On the negative side, the historic process today is the possibility of our spinning down futher into the ever increasing disunity and chaos of ethnic and religious wars, of millions of refugees, of financial ruin as one result of the globalization of unstable finance, of hunger, disease, and ignorance.

On the opposite side is the possibility, as the Wiener Kreis Manifesto of 1929 put it, "Returning, after a metaphysical interlude, to a unified picture of the world.” And the reason for my cautious optimism that the positive side may yet win, is something that those theoreticians of unification in Vienna, who started only with a unification of science and philosophy, could not have expected, except in their most utopian dreams. For there have been forming, increasingly numerous global, integrated, organizations. 
One thinks of institutions, with all their deficiencies, such as the United Nations, UNESCO, the European Union, the World Trade Organization, the World Health and Food Organizations, the International Criminal Courts, the World Bank, the International Atomic Agency, and hundreds of others of that sort. Look around you—at the huge number of nongovernmental organizations housed in Austria. Such experiments are presenting themselves as a source of hope, not only institutionally but also intellectually. A practical aspect of intellectual globalization is interdisciplinarity, especially in the

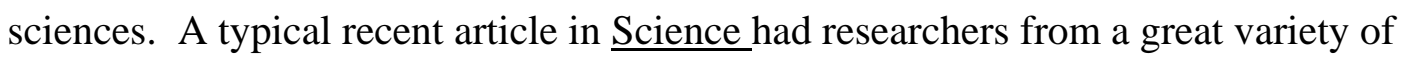
specializations, from over 100 institutions in 16 nations, working together on a genome project on drosphila, the fruit fly. At the LHC collider in CERN, some 2500 persons, most working at a distance, are involved in a new experiment. Mega-teams are working on environmental science, and so forth.

Within contemporary natural sciences there is now actually a highly accelerating movement of integration, which the Wiener Kreis only hoped for. The big new word is Integration. To give one parochial example, at my university a big new building is being finished, which has the astonishing name: Laboratory for Integrated Science and Engineering. All of natural science, all of Engineering! At least, that is the invitation to scientists. And in addition, there is now worldwide a consciousness that there is some underlying unity in science, perhaps not of the Theory-of-Everything variety but of a different, operational kind. That is exemplified in the ceaseless borrowing connecting diverse traditions and disciplines. In principle, any two research efforts, however removed in time, in subject or in purpose, may well turn out to be genealogically connected. And in the limit, the whole of natural science may be represented as one 
thickly linked continuum, which can be divided into distinct disciplines and traditions only in an arbitrary way. However they may differ, the multitudinous projects of the sciences share in and emerge from a common history.

The increasing intellectual and institutional globalizations, together with the rapid integration among the separate sciences allow me to conclude with a sincere hope.

Let me dare to say it here: Something new is trying to be born in our world, something on which we must place our bets. It is a new variation of an intellectual and living tendency toward Einheit, of which the Wiener Kreis was an early voice of prophecy.

The last paragraph of the 1929 Menifesto began as follows:

"So steht die wissenschaftliche Weltauffassung dem Leben der

Gegenwart nahe...gibt es viele...die angesichts der soziologischen

Lage der Gegenwart, hoffnungsfroh der weiteren Entwicklung entgengensehen."

That hope was not to be in the tragic 20th century. But it can live again, and your studies here are necessary sources of a better understanding toward the new Auffassung der Welt. 